\title{
PERS DAN REPRESENTASI CITRA PEREMPUAN DALAM POLITIK (ANALISIS WACANA PEMBERITAAN POLITISI PEREMPUAN INDAH DHAMAYANTI PUTRI DI HARIAN LOMBOK POST DAN SUARA NTB PERIODE
}

\author{
Oleh : Diyah Indiyati ${ }^{1}$, Hartin Nur Khusnia ${ }^{2}$, Dian Lestari Miharja ${ }^{3}$ \\ University of Mataram, Communication Science \\ University of Mataram, Communication Science \\ University of Mataram, Communication Science
}

\begin{abstract}
ABSTRAK
Media massa dalam memberitakan sebuah fakta berada di tengah realitas sosial yang sarat dengan berbagai kepentingan yang kompleks. Sebagai institusi yang memiliki kekuatan membentuk opini publik, pers dapat memberikan pengaruh positif maupun negative, tergantung pada kepentingan yang diwakili. Termasuk dalam merepresentasikan citra perempuan dalam politik melalui pemberitaannya. Melalui teks pemberitaannya media membangun sebuah realitas tentang citra perempuan dalam politik. Di mana realitas yang dibangun oleh media tersebut bukanlah realitas yang bebas nilai.

Penelitian ini akan mengkaji bagaimana citra politisi perempuan Indah Dhamayanti Putri dalam pemberitaan suratkabar Lombok Post dan Suara NTB periode Februai-Mei 2016. Kedua suratkabar ini merupakan harian yang memiliki oplah terbesar di NTB. Artinya, informasi yang disajikan oleh dua surat kabar ini paling banyak diakses oleh masyarakat NTB. Bagaiamana realitas tentang kepemimpian perempuan dalam skala lokal direpresentasikan oleh kedua harian tersebut, tentunya akan mempengaruhi cara pandang dan cara bersikap masyarakat terhadap kepemimpinan perempuan. Terlebih secara historis, Indah Dhamayanti Putri merupakan pemimpin perempuan pertama di wilayah NTB.

Berita tentang kepemimpinan Indah Dhamayanti Putri berupa profil sebagai kepala daerah, aktivitas politik, kebijakan dan program-program yang dimiliki dianalisis menggunakan metode analisis wacana Norman Fairclough, dengan menganalisi mikro teks dengan konteks masyarakat yang makro. Pusat analisisnya lebih pada bagaimana bahasa terbentuk dan dibentuk dari relasi sosial dan konteks sosial tertentu. Fairclough membagi analisis wacana dalam tiga dimensi, yakni teks, praktik kewacanaan (discourse practice) dan praktik sosio-kultural (socio-cultural practice). Dari hasil penelitian yang dilakukan, terlihat bahwa politisi perempuan Indah Dhamayanti Putri masih dicitrakan dalam kerangka stereotype baik dari sisi penampilan fisiknya, figur atau perannya sebagai istri dan ibu masih melekat dalam wacana tekstual pemberitaan dua media massa.
\end{abstract}


Keywords: Representasi politisi perempuan, citra, analisis wacana.

\begin{abstract}
The mass media fact report within social reality comes with a complexities of interest. As an institution which has the power to shape public opinion, the press also able to give influence both positive and negative, depend on the interests represented. Including while representing the image of women in politics through its news report. Through the news report, text media construct a reality of a women in politics image. In which this reality constructed by the media is not a value-free.

This study analyses the media discourse of a woman politician recently elected as a Bupati (which has the same rank as a Mayor) of Bima District Indah Dhamayanti Putri in the local news media coverage Lombok Post and Suara NTB from the February to May 2016. Both newspaper are daily newspaper which contribute the largest circulation in the province of West Nusa Tenggara. Hence, the two media are the most accessed printed media in the province. How the reality of woman leadership in local scale constructed by this two dailies will certainly influence the view of the people, and the way people behave towards this leadersship. Moreover Indah Dhamayanti Putri is the first female leader in the province of West Nusa Tenggara.

The news about Indah Dhamayanti Putri leadership analyzed in this study consist of her profile as the Bupati, her political activities, polocies and programs. The news analyzed using critical discourse analysis method from Norman Fairclough model, by analyzing the text in the macro-micro societal context. FOcus of the analysis are more on how language is formed and shaped from social relationships and a certain social context. Fairclough divide discourse analysis in three dimensions, textual analysis, discourse practice and socio-cultural practices . From the research conducted, it appears that women politicians Indah Dhamayanti Putri are perceived in terms of stereotypes both in terms of physical appearance, figure or her role as wife and mother are still inherent in the discourse of textual reports of two mass media.
\end{abstract}

Keywords: Representation women politician, image, discourse analysis 


\section{I . PENDAHULUAN}

Di dalam masyarakat modern mana pun, media memainkan peran penting untuk perkembangan politik masyarakatnya. Pers kerap disebut-sebut sebagai salah satu pilar demokrasi. Kebebasan berekspresi dan menyampaikan informasi merupakan dasar penting untuk sistem demokrasi dan telah dikukuhkan dalam semua dokumen hak asasi manusia yang dikeluarkan setelah Perang Dunia Kedua (Adam, dalam Mirza, ed., 2000:7). Media massa dianggap semestinya berfungsi pertama dan terutama sebagai pewarta kebenaran dan kenyataan. Kepercayaan itu terbentuk oleh sebuah paradoks. Ia muncul justru karena adanya kesadaran umum bahwa ternyata media massa kita tidak berfungsi seperti itu. Terdapat kesenjangan besar antara yang dianggap semestinya dan yang terbukti telah terjadi (Sobur, 2002: 32).

Media massa dalam memberitakan sebuah fakta berada di tengah realitas sosial yang sarat dengan berbagai kepentingan yang kompleks dan beragam, dari kepentingan ideologi hingga kepentingan kapitalisme pemilik modal. Sebagai institusi yang mempunyai kekuatan untuk membentuk opini publik, pers dapat memberikan pengaruh positif maupun negatif, bergantung pada kepentingan yang diwakili. Termasuk dalam merepresentasikan citra perempuan dalam dunia politik melalui pemberitaannya. Melalui teks pemberitaannya media membangun sebuah realitas tentang citra perempuan dalam politik. Dimana realitas yang dibangun oleh media tersebut bukanlah realitas yang bebas nilai, namun realitas yang terbentuk dalam sebuah konteks sosial yang kompleks.

Penelitian ini akan mengkaji bagaimana citra perempuan direpresentasikan dalam pemberitaan politik oleh pers. Fokus penelitian akan dititikberatkan pada berita tentang kepemimpinan sosok politisi perempuan Indah Dhamayanti Putri di harian Lombok Post dan Suara NTB periode Februari sampai dengan Mei 2016. Berita tentang kepemimpinan Indah Dhamayanti Putri dapat berupa profilnya sebagai kepala daerah, aktivitas politiknya, kebijakan dan program-program selama kepemimpinannya. 
Lombok Post dan Suara NTB adalah dua surat kabar lokal dengan oplah terbesar di Nusa Tenggara Barat. Artinya, informasi yang disajikan oleh ke dua harian lokal itu paling banyak diakses oleh masyarakat NTB. Bagaimana realitas tentang perempuan dalam politik, khususnya kepemimpinan perempuan dalam skala lokal direpresentasikan oleh kedua harian tersebut, tentunya akan mempengaruhi pembentukan cara pandangan dan cara bersikap masyarakat terhadap kepemimpinan politik perempuan. Terlebih, secara historsi kepala daerah Indah Dhamayati Putri adalah sosok pemimpin perempuan pertama di wilayah Nusa Tenggara Barat. Sementara pemilihan periode penelitian dari bulan Februari sampai dengan Mei 2016 didasarkan pada alasan bahwa periode tersebut merupakan periode awal kepemimpinan Indah Dhamayanti Putri. Secara umum dalam sebuah kepemimpinan baru, program atau pun kebijakan yang di hasilkan akan mendapatkan sorotan publik pada awal-awal kepemimpinan. Oleh karenanya dalam penelitian ini akan dikaji bagaimana wacana tentang politisi perempuan ditampilkan oleh masing-masing surat kabar lokal.

\section{A. Masalah Penelitian}

Teks berita yang ditampilkan oleh media bukanlah teks yang bebas nilai, namun teks yang diproduksi dalam konteks sosial dan budaya yang kompleks. Proses produksi teks yang demikian tentunya akan membentuk wacana tentang realitas yang disajikan oleh media. Oleh karenanya penelitian ini akan mengkaji "Bagaimana surat kabar Lombok Post dan Suara NTB merepresentasikan citra politisi perempuan Indah Dhamayanti Putri dalam pemberitaannya?"

\section{B. Tujuan Penelitian}

Berdasarkan pokok permasalahan bagaimana surat kabar Lombok Post dan Suara NTB merepresentasikan citra politisi perempuan Indah Dhamayanti Putri dalam pemberitaannya, maka tujuan penelitian ini adalah untuk mengetahui representasi citra politisi perempuan Indah Dhamayanti Putri dalam pemberitaan pada surat kabar Lombok Post dan Suara NTB. 


\section{TINJAUAN PUSTAKA}

\section{Analisis Wacana}

Analisis wacana adalah salah satu alternatif dari analisis isi selain analisis isi kuantitatif yang dominan dan banyak dipakai. Jika analisis kuantitatif lebih menekankan pada pertanyaan "apa" (what), analisis wacana lebih melihat pada "bagaimana" (how) dari pesan atau teks komunikasi. Melalui analisis wacana kita bukan hanya mengetahui bagaimana isi teks berita, tetapi juga bagaimana pesan itu disampaikan. Dengan melihat bagaimana bangunan struktur kebahasaan tersebut, analisis wacana lebih bisa melihat makna yang tersembunyi dari suatu teks (Eriyanto, 2001: xv). Analisis wacana memungkinkan kita melihat bagaimana pesan-pesan diorganisasikan, digunakan dan dipahami. Di samping itu, analisis wacana juga dapat memungkinkan kita melacak variasi cara yang digunakan oleh komunikator (penulis, pembicara, sutradara) dalam upaya mencapai tujuan atau maksud-maksud tertentu melalui pesan-pesan berisi wacana-wacana tertentu yang disampaikan. Hal ini mencakup berbagai hal termasuk, misalnya, bagaimana proses-proses simbolik digunakan khususnya terkait dengan kekuasaan, ideologi, dan lambang-lambang bahasa serta apa fungsinya (Pawito, 2007: 170).

Dengan demikian, analisis wacana mempunyai karakteristik tersendiri yang membedakan dengan analisis isi kuantitatif. Berikut merupakan karakteristik dari analisis wacana (Eriyanto, 2001: 8 - 14):

a. Tindakan.

Wacana dipahami sebagai sebuah tindakan (action). Dengan pemahaman semacam ini mengasosiasikan wacana sebagai bentuk interaksi. Dengan pemahaman semacam itu ada konsekuensi bagaimana wacana harus dipandang. Pertama, wacana dipandang sebagai sesuatu yang bertujuan, apakah untuk mempengaruhi, mendebat, membujuk, menyangga, bereaksi, dan sebagainya. Kedua, wacana dipahami sebagai sesuatu yang diekspresikan 
secara sadar, terkontrol, bukan sesuatu yang diluar kendali atau diekspresikan di luar kesadaran.

b. Konteks.

Analisis wacana mempertimbangkan konteks dari wacana, seperti latar, situasi, peristiwa, dan kondisi. Wacana di sini dipandang, diproduksi, dimengerti, dan dianalisis pada konteks tertentu. Guy Cook menyebut ada tiga hal yang sentral dalam pengertian wacana: teks, konteks dan wacana. Teks adalah semua bentuk bahasa, seperti kata-kata, ucapan, musik, gambar, efek suara, citra, dan sebagainya. Konteks memasukkan semua situasi dan hal yang berada di luar teks dan mempengaruhi pemakaian bahasa, seperti partisipan dalam bahasa, situasi di mana teks tersebut diproduksi, fungsi yang dimaksudkan dan sebagainya. Wacana kemudian dimaknai sebagai teks dan konteks bersama-sama dalam suatu proses komunikasi.

c. Historis

Menempatkan wacana dalam konteks sosial tertentu, berarti wacana diproduksi dalam konteks tertentu dan tidak dapat dimengerti tanpa menyertakan konteks yang menyertainya. Salah satu aspek penting untuk bisa mengerti teks adalah dengan menempatkan wacana itu dalam konteks historis tertentu.

d. Kekuasaan

Setiap wacana yang muncul, dalam bentuk teks, percakapan, atau apa pun, tidak dipandang sebagai sesuatu yang alamiah, wajar, dan netral tetapi merupakan bentuk pertarungan kekuasaan. Konsep kekuasaan adalah salah satu kunci hubungan antara wacana dengan masyarakat. Kekuasaan dalam hubungannya dengan wacana, penting untuk melihat apa yang disebut kontrol. Bentuk kontrol terhadap wacana bida bermacam-macam. Bisa berupa kontrol atas konteks, yang secara mudah dapat dilihat dari siapakah yang boleh dan harus berbiacar, sementara siapa pula yang hanya bisa mendengar dan mengiyakan. Selain konteks, kontrol juga diwujudkan dalam bentuk 
mengontrol struktur wacana. Seseorang yang mempunyai lebih besar kekuasaan bukan hanya menentukan bagian mana yang perlu ditampilkan dan mana yang tidak tetapi juga bagaimana ia harus ditampilkan.

e. Ideologi

Dalam analisis wacana yang bersifat kritis, teks, percakapan, dan lainnya adalah bentuk praktik ideologi tertentu. Teori-teori klasik tentang ideologi di antaranya mengatakan bahwa ideologi dibangun oleh kelompok yang dominan dengan tujuan untuk mereproduksi dan melegitimasi dominasi mereka. Salah satu strategi utamanya adalah dengan membuat kesadaran kepada khalayak bahwa dominasi itu diterima secara taken for granted. Wacana dalam pendekatan semacam ini dipandang sebagai medium melalui mana kelompok yang dominan mempersuasi dan mengkomunikasikan kepada khalayak produksi kekuasaan dan dominasi yang mereka miliki, sehingga tampak abasah dan benar.

Komunikasi dalam konteks analisis wacana terdiri dari tindakan-tindakan kompleks yang kemudian membentuk pesan di mana dikandung wacana tertentu. Komunikator menggunakan wacana untuk mencapai tujuan, dan cara yang ditempuh dalam penggunaa wacana pada dasarnya terikat oleh konteks dimana sebuah teks diproduksi.

\section{Representasi}

Istilah representasi itu sendiri menunjuk pada menunjuk pada bagaimana seseorang, satu kelompok, gagasan atau pendapat tertentu ditampilkan dalam pemberitaan. Representasi penting dalam dua hal. Pertama, apakah seseorang, kelompok, atau gagasan tersebut ditampilkan sebagaimana mestinya. Kata semestinya ini mengacu pada apakah seseorang atau kelompok itu diberitakan apa adanya, ataukah diburukkan. Penggambaran yang tampil bisa jadi adalah penggambaran yang buruk dan cenderung memarjinalkan seseorang atau kelompok tertentu. Di sini hanya citra yang buruk saja yang ditampilkan 
sementara citra atau sisi yang baik luput dari pemberitaan. Kedua, bagaimana representasi tersebut ditampilkan. Dengan kata, kalimat, aksentuasi, dan bantuan foto macam apa seseorang, kelompok, atau gagasan tersebut ditampilkan dalam pemberitaan kepada khalayak (Eriyanto, 2001: 113). Kedua hal penting tersebut berpengaruh terhadap konstruksi makna yang dibuat oleh media terhadap sebuah realitas.

Saat menghadirkan sebuah berita, menurut John Fiske ada tiga proses yang dihadapi oleh seorang wartawan. Level pertama, adalah peristiwa yang ditandakan (encode) sebagai realitas. Bagaimana peristiwa itu dikonstruksi sebagai realitas oleh wartawan/media. Dalam bahasa gambar (terutama televisi) ini umumnya berhubungan dengan aspek seperti pakaian, lingkungan, ucapan, dan ekspresi. Di sini, realitas selalu siap ditandakan, ketika kita menganggap dan mengkonstruksi peristiwa tersebut sebagai sebuah realitas. Level kedua, ketika kita memandang sesuatu sebagai realitas, pertanyaan berikutnya adalah bagaimana realitas itu digambarkan. Di sini kita menggunakan perangkat secara teknis. Dalam bahasa tulis, alat teknis itu adalah kata, kalimat atau proposisi, grafik, dan sebagainya. Dalam bahasa gambar/televisi, alat itu berupa kamera, pencahayaan, editing, atau musik. Pemakaian kata-kata, kalimat, atau proposisi tertentu akan membawa makna tertentu ketika diterima oleh khalayak. Level ketiga, bagaimana peristiwa tersebut diorganisir ke dalam konvensi-konvensi yang diterima secara ideologis. Bagaimana kode-kode representasi dihubungkan dan diorganisasikan ke dalam koherensi sosial seperti kelas sosial, atau kepercayaan dominan yang ada dalam masyarakat (patriarki, materialisme, kapitalisme, dan sebagainya). Menurut Fiske, ketika kita melakukan representasi tidak bisa dihindari kemungkinan menggunakan ideologi tersebut (Eriyanto, 2001: 115).

Dalam tataran teks, unsur utama yang menciptakan representasi adalah unsur kebahasaan. Media massa menggunakan bahasa dalam menggambarkan realitas. Menurut Eriyanto (2001: 116), terdapat dua proses yang dilakukan media 
dalam memaknai realitas. Pertama, memilih fakta. Proses memilih fakta ini didasarkan pada asumsi wartawan tidak mungkin melihat peristiwa tanpa perspektif. Kedua, menuliskan fakta. Proses ini berhubungan dengan bagaimana fakta yang dipilih itu disajikan kepada khalayak. Gagasan itu diungkapkan dengan kata, kalimat, dan proposisi apa, dengan bantuan aksentuasi foto dan gambar apa, dan sebagainya. Kedua proses tersebut tentunya bukan hanya sekedar teknis jurnalistik, namun lebih jauh merupakan sebuah praktik representasi. Di mana media melakukan strategi dalam memaknai realitas untuk dihadirkan kepada khalayak.

\section{Politik dan Ideologi Patriarkhi}

Politik dalam konteks isu perempuan didefinisikan sebagai "segala" usaha, kegiatan, dan upaya yang bertujuan mempengaruhi proses kebijakan dan perundangan yang berkaitan dengan isu-isu perempuan (Sugiarti, dkk: 2003: 5657). Terkait dengan isu perempuan dalam politik, akan selalu kita temukan sebuah sistem yang diskriminatif terhadap perempuan. Secara kuantitas jumlah perempuan lebih banyak jika dibandingkan dengan laki-laki, baik di tingkat masyarakat Indonesia maupun internasional, namun banyaknya jumlah perempuan itu tidak menjamin representasi perempuan dalam dunia politik. Hal ini tidak dapat dilepaskan dari ideologi patriarki yang berkembang di Indonesia.

Dalam tradisi patriarkhi pada umumnya, di Indonesia pada khususnya, dunia politik dikategorikan sebagai dunia laki-laki dan oleh karenanya, dunia perempuan tersingkir dari dunia tersebut. Kaum laki-lakilah yang menetapkan dan memutuskan berbagai kebijakan dan perundangan, dari dunia tersebut, termasuk yang menyangkut hak-hak dan kepentingan perempuan (Macioni 1987; Susanto 1993; Suryokumoro 1992; dalam Indriyati, dkk: 2005: 16). Menurut Arivia Negara yang menganut sistem patriarkhi atau secara sederhana disebut sebagai Negara patriarkhis adalah Negara yang mempromosikan dan memelihara praktekpraktek yang secara sistematis menindas perempuan. Penindasan perempuan 
dilihat dari struktur keluarga dan rumah tangga serta kebijaksanaan yang diterapkan pada kedua bidang tersebut. Biasanya kebijakan tersebut bersifat diskriminatif, atau menggambarkan status kebebasan dan ekonomi perempuan (Jurnal Perempuan 07: 10-11, dalam Indriyati, dkk, 2005: 16).

Istilah patriarkhi pada awalnya digunakan oleh Max Weber untuk mengacu pada sistem sosial politik tertentu di mana seorang ayah, berkat posisinya dalam rumah tangga/keluarga, bisa mendominasi anggota jaringan keluarga luasnya dan menguasai ekonomi dari kesatuan kekerabatan tersebut (Saptari \& Hozlner, 1997). Patriarkhi yang menggambarkan dominasi laki-laki atas perempuan dan anak-anak dalam keluarga ini berlanjut pada dominasi lakilaki dalam semua lingkup kemasyarakatan lainnya. Dalam hal ini patriarkhi didefiniskan bahwa laki-laki memegang kekuasaan atas semua peran penting dalam masyarakat, pemerintahan, militer, pendidikan, industri, agama, dan sebagainya (Handayani dkk, 2002).

Ideologi patriarkhi ini kemudian menghegemoni masyarakat melalui sistem dan struktur Negara, yang kemudian mempengaruhi cara hidup, cara pandang, dan cara berpikir masyarakat. Dalam konteks politik, ideologi patriarkhi telah menempatkan laki-laki dalam posisi yang dominan, di mana secara struktural dan kultural laki-laki medominasi dunia politik. Hal ini membawa dampak pada keterlibatan perempuan dalam politik. Pandangan bahwa politik itu kotor, politik itu keras, bertentangan dengan stereotipe perempuan yang halus, lembut, penyabar.

BAB III

METODOLOGI PENELITIAN 
Metode penelitian ini adalah analisis wacana dengan pendekatan perubahan sosial (sociocultural change approach), yaitu melihat wacana sebagai praktik sosial. Michael Foucault mengatakan bahwa pengguliran wacana dibatasi dan bahkan ditentukan atau dikontrol oleh kekuatan-kekuatan pranata sosial (social institutions) yang kompleks yang ada di dalam masyarakat, dan bukan semata merupakan persoalan bahasa (Keiko Matsuki, 1996: 351). Analisis wacana (discourse analysis) adalah suatu cara atau metode untuk mengkaji wacana yang terkandung di dalam pesan-pesan komunikasi baik secara tekstual maupun kontekstual. Metode analisis wacana pendekatan sosiokultural akan digunakan untuk menganalisis teks berita tentang representasi perempuan dalam politik di harian Lombok Post dan Suara NTB.

\section{Metode Penelitian}

Metode penelitian yang digunakan dalam penelitian ini adalah analisis wacana, yaitu untuk melihat bagaimana media menggambarkan realitas tentang perempuan dalam politik, bagaimana bahasa yang digunakan oleh media dalam mengembangkan wacana tentang perempuan dalam politik. Peneliti menggunakan model analisis wacana kritis Norman Fairclough, dikarenakan model ini menganalisis teks yang mikro dengan konteks masyarakat yang makro. Pusat analisis dari model Norman Fairclough adalah bagaimana bahasa itu terbentuk dan dibentuk dari relasi sosial dan konteks sosial tertentu. Fairclough membagi analisis wacana dalam tiga dimensi, yaitu teks, discourse practice, dan sociocultural practice.

\section{Teknik Pengumpulan Data}

Teknik pengumpulan data yang digunakan dalam penelitian ini terdiri dari tiga tahap yaitu:

a. Tahap pertama, pada tahap ini akan dilakukan pengumpulan berita dari dua surat kabar yang diteliti yaitu harian Lombok Post dan Suara NTB tentang kepemimpinan kepala daerah perempuan Indah Dhamayanti Putri selama periode Februari sampai dengan Mei 2016. Segala berita yang berkaitan 
dengan kepemimpinan Indah Dhamayanti Putri akan menjadi sampel dalam penelitian ini. Berita yang dimaksud dapat berupa profil, aktifitas politik, kebijakan politik.

b. Tahap kedua, pada tahap ini akan dilakukan wawancara secara mendalam dengan redaktur dan wartawan dari masing-masing media. Pengumpulan data ini bertujuan untuk menganalisis discourse practice pada masing-masing surat kabar.

c. Tahap ketiga, pada tahap ini akan dilakukan penelusuran dan studi pustaka untuk menunjang dalam menganalisis sociocultural practice dari wacana yang dikembangkan oleh masing-masing surat kabar.

\section{Fokus penelitian}

Unit analisis dalam penelitian ini adalah pemberitaan tentang perempuan dalam politik. Fokus penelitian akan dititikberatkan pada berita tentang kepemimpinan sosok politisi perempuan Indah Dhamayanti Putri di harian Lombok Post dan Suara NTB periode Februari sampai dengan Mei 2016. Berita tentang kepemimpinan Indah Dhamayanti Putri dapat berupa profilnya sebagai kepala daerah, aktivitas politiknya, kebijakan dan program-program selama kepemimpinannya.

Lombok Post dan Suara NTB adalah dua harian lokal dengan oplah terbesar di Nusa Tenggara Barat. Artinya, informasi yang disajikan oleh ke dua harian lokal itu paling banyak diakses oleh masyarakat NTB. Bagaimana realitas tentang perempuan dalam politik, khususnya kepemimpinan perempuan dalam skala lokal direpresentasikan oleh kedua harian tersebut, tentunya akan mempengaruhi pembentukan cara pandangan dan cara bersikap masyarakat terhadap kepemimpinan politik perempuan. Terlebih, secara historsi kepala daerah Indah Dhamayati Putri adalah sosok pemimpin perempuan pertama di wilayah Nusa Tenggara Barat. Sementara pemilihan periode penelitian dari bulan Februari sampai dengan Mei 2016 didasarkan pada alasan bahwa periode tersebut merupakan periode awal kepemimpinan Indah Dhamayanti Putri. Secara umum 
dalam sebuah kepemimpinan baru, program atau pun kebijakan yang di hasilkan akan mendapatkan sorotan publik pada awal-awal kepemimpinan.

\section{Teknik Analisis Data}

Untuk melakukan kajian atas wacana representasi perempuan dalam politik di harian Lombok Post dan Suara NTB, maka peneliti menggunakan model analisis wacana yang ditawarkan oleh Norman Fairclough. Fairclough membagi wacana dalam tiga dimensi, yaitu teks, discourse practice, dan sociocultural practice (Eriyanto, 2001: 286).

Teks dianalisis secara linguistik dengan melihat kosakata, semantik dan tata kalimat. Koherensi dan kohesivitas juga dimasukkan, bagaimana antarkata atau kalimat tersebut digabung sehingga membentuk pengertian. Elemen-elemen yang dianalisis tersebut dipakai untuk melihat ideasional, relasi, dan identitas. Ketiga elemen dasar model Fairclough dapat digambarkan dalam table berikut:

\begin{tabular}{|l|l|}
\hline \multicolumn{1}{|c|}{ UNSUR } & \multicolumn{1}{c|}{ YANG INGIN DILIHAT } \\
\hline Representasi & $\begin{array}{l}\text { Bagaimana peristiwa, orang, kelompok, situasi, keadaan, } \\
\text { atau apa pun ditampilkan dan digambarkan dalam teks. }\end{array}$ \\
\hline Relasi & $\begin{array}{l}\text { Bagaimana hubungan antara wartawan, khalayak, dan } \\
\text { partisipasi berita ditampilkan dan digambarkan dalam teks }\end{array}$ \\
\hline Identitas & $\begin{array}{l}\text { Bagaimana identitas wartawan, khalayak, dan partisipasi } \\
\text { berita ditampilkan dan digambarkan dalam teks. }\end{array}$ \\
\hline
\end{tabular}

Tabel 4.1 Tiga elemen dasar yang dianalisis dalam teks menurut Norman Fairclough

Discourse practice adalah dimensi yang berhubungan dengan proses produksi dan konsumsi teks. Teks berita melibatkan praktik diskursus yang rumit dan kompleks. Praktik wacana inilah yang menentukan bagaimana teks tersebut terbentuk. Eriyanto (2001: 317) menyebutkan paling tidak ada tiga elemen yang mempengaruhi produksi suatu wacana berita. Pertama, dari sisi individu 
wartawan itu sendiri. Kedua, dari sisi bagaimana hubungan antara wartawan dengan struktur organisasi media, baik dengan sesama anggota redaksi maupun dengan bidang lain dalam satu media. Ketiga, praktik kerja/rutinitas kerja dari produksi berita mulai dari pencarian berita, penulisan, editing sampai muncul sebagai tulisan dimedia.

Sociocuktural practice adalah dimensi yang berhubungan dengan konteks diluar teks, dimana konteks sosial di luar media mempengaruhi wacana yang muncul dalam media. Fairclough membuat tiga level analisis pada sociocultural practice, yaitu pertama, situasional: bahwa konteks sosial yang khas mempengaruhi produksi teks berita. Kedua, institusioal: melihat bagaimana pengaruh institusi organisasi-baik internal media maupun kekuatan-kekuatan eksternal di luar media_-dalam praktik produksi wacana. Faktor institusi yang penting adalah institusi yang berhubungan dengan ekonomi media, karena proses produksi berita tidak dapat dilepaskan dari pengaruh ekonomi media yang pada akhirnya akan berpengaruh terhadap wacana yang muncul dimunculkan media. Selain ekonomi media, faktor politik juga berpengaruh terhadap produksi wacana. Ketiga, sosial: Fairclough menegaskan bahwa wacana yang muncul dalam media ditentukan oleh perubahan masyarakat. Dalam level sosial, budaya masyarakat, misalnya, turut menentukan perkembangan wacana media.

Pada tahap analisis, ketiga tahap itu dilakukan secara bersama-sama. Analisis teks bertujuan mengungkap makna melalui praktik bahasa. Discourse practice menghubungkan anatar teks dengan konteks sosial budaya (socialcultural practice). Melalui model ini, Fairclough ingin menegaskan bahwa wacana media sesungguhnya adalah suatu bidang yang kompleks. Untuk memahami wacana kita tidak dapat melepaskan dari konteksnya. Untuk menemukan "realitas" di balik teks kita memerlukan penelusuran atas konteks produksi teks, konsumsi teks, dan aspek sosial budaya yang mempengaruhi pembuatan teks. 


\section{PEMBAHASAN}

Media merupakan instrumen dalam proses meraih perhatian publik. Teks media bukanlah sekadar cermin yang merefleksikan "realitas", namun juga mengkonstruksi definisi hegemonik tentang apa yang harus diterima sebagai sebuah "realitas". Definisi-definisi tersebut muncul sebagai sesuatu yang tak terelakkan dan bisa diterima nalar (Carter, Steiner, 2003:2).

Karenanya media memiliki kekuatan untuk mempengaruhi persepsi dan keyakinan masyarakat lewat gambaran-gambaran yang diwujudkannya dalam teks. Demikian halnya terkait dengan gambaran politisi perempuan yang dimunculkan dalam teks media. Partisipasi perempuan dalam kancah politik di Indonesia masih relatif minim. Dalam data beberapa tahun terakhir terlihat kuota $30 \%$ yang ditargetkan untuk keterwakilan perempuan di parlemen tidak pernah terpenuhi. Bahkan data Komisi Pemilihan Umum (KPU) yang dilansir dari www.kpu.go.id hasil Pemilu legislatif tahun 2014 lalu menunjukkan penurunan persentase keterwakilan perempuan dalam jajaran anggota DPR RI dari 18,04\% pada Pemilu 2009 menjadi 17,32\% pada Pemilu 2014 lalu. Sedangkan anatomi jumlah anggota DPD perempuan pada Pemilu 2014 lalu masih berada di posisi $26 \%$.

Data yang diperoleh KPU tidak hanya memberikan gambaran di tingkat pusat, akan tetapi juga memberikan gambaran serupa di tingkat daerah. Keterwakilan perempuan di posisi legislatif masih rendah, demikian halnya di tingkat eksekutif. Kepemimpinan perempuan masih sangat jarang terlihat baik di level SKPD maupun di legislatif.

Terkait hal ini, Provinsi Nusa Tenggara Barat memberikan warna yang berbeda pada tahun 2016 ini. Dalam Pilkada Kabupaten Bima, muncul figur politisi perempuan yang tampil sebagai pemenang, yakni Indah Dhamayanti Putri. Di level legislatif pun, DPRD Provinsi NTB mempercayakan kepemimpinan Dewan kepada 
Hj Baiq Isvie Rupaeda. Tentunya hal ini menjadi kabar baik bagi keterwakilan perempuan di parlemen dan eksekutif di wilayah NTB.

Dengan fenomena tersebut, dalam penelitian ini peneliti ingin melihat lebih jauh apa yang ditampilkan oleh media mengenai sosok kepemimpinan perempuan di Kabupaten Bima yang diwakili oleh sosok Indah Dhamayanti Putri. Secara umum, pemberitaan pascaterpilihnya Indah Dhamayanti Putri sebagai Bupati Bima di harian Lombok Post menonjolkan berita-berita positif, melalui teks berita lempang terkait program terjadwal Bupati. Sementara, di harian Suara NTB cenderung menampilkan berita-berita yang sifatnya mengkritisi kinerja pemerintah daerah Bima di bawah kepemimpinan Indah Dhamayanti Putri.

Di sisi lain, meskipun yang ditonjolkan di harian Lombok Post adalah berita positif namun dari teks berita yang muncul masih kerap menyiratkan sisi feminis, stereotip, subordinasi terhadap perempuan yang terepresentasikan dalam diksi yang digunakan oleh wartawan. Begitu pula teks berita yang disajikan oleh harian Suara NTB, selain penggunaan diksi yang merepresentasikan sisi feminis, subordinasi, juga dalam rangkaian antarkalimat merepresentasikan kinerja Bupati perempuan yang tidak piawai dalam memimpin pemerintahan. Berikut adalah analisis wacana pemberitaan politisi perempuan Indah Damayanti Putri di harian Lombok Post dan Suara NTB.

\section{Analisis Wacana Pemberitaan Politisi Perempuan Indah Damayanti Putri di Surat Kabar Harian Lombok Post}

Ketika membincangkan kiprah perempuan dalam politik, seringkali muncul stereotip dan subordinasi terhadap perempuan. Stereotip atau biasa disebut pelabelan sering memunculkan anggapan negatif dan melahirkan ketidakadilan. Dalam hal ini, pandangan terhadap perempuan bahwa tugas dan fungsinya melaksanakan tugas di rumah adalah ketidakadilan gender. Label kaum perempuan sebagai ibu rumah tangga akan sangat merugikan perempuan yang ingin aktif di birokrasi, bisnis, dan lain sebagainya. Sementara, subordinasi adalah keyakinan dan perilaku yang 
menunjukkan bahwa salah satu jenis kelamin dianggap penting dibandingkan jenis kelamin lainnya. Anggapan bahwa kedudukan laki-laki lebih tinggi dibandingkan perempuan adalah salah satu contoh subordinasi. Selain itu, banyak sisi yang menempatkan perempuan dibawah laki-laki, seperti tradisi, tafsir agama, dan aturan birokrasi.

Stereotip dan subordinasi terhadap perempuan, khususnya di ranah politik, terbentuk karena budaya patriarkhi yang berkembang dalam sistem sosial masyarakat Indonesia. Budaya patriarkhi adalah budaya dimana laki-laki memegang kekuasaan atas semua peran penting dalam masyarakat, pemerintah, militer, pendidikan, industri, agama, dan sebagainya. Berkembangnya budaya patriarkhi dalam sistem sosial masyarakat Indonesia berdampak pada minimnya peran serta perempuan di berbagai sektor publik, khususnya dalam politik.

Media massa mempunyai andil yang cukup signifikan dalam melanggengkan pelabelan dan subordinasi terhadap perempuan, melalui berbagai bentuk sajiannya, baik iklan, film, sinetron, berita, dan sebagainya. Terkait peran media dalam melanggengkan stereotip dan subordinasi terhadap perempuan, dalam konteks penelitian ini dapat kita cermati dalam beberapa teks berita yang disajikan oleh harian Lombok Post. Teks yang merepresentasikan citra perempuan sebagai ibu rumah tangga, serta melekatkan kekuatan penting kaum laki-laki yang membayang-bayangi kepemimpinan perempuan. Misalnya terdapat dalam teks berita:

"Saya sangat tidak sepakat ada perayaan hari valentine", katanya, kemarin. Ibu dua anak ini menjelaskan..... "Kita jangan mau disesatkan. Kita punya agama sebagai pedoman hidup," tegas istri mendiang H Ferry Zulkarnain ini. (Lombok Post, 13/2/2016)

....."Setelah ini kita ke kuburan. Saya harus berziarah ke makam almarhum Dae Ferry (Sapaan H Ferry Zulkarnain)," katanya. "Mobil ini dulu dibeli almarhum pada periode kedua kepemimpinannya sebagai Bupati Bima. Saya tidak tahun selama ini dipakai oleh siapa," tutur Daefullah, ketua Tim Pemenangan Dinda. Sampai di kuburan, Dae Dinda yang didampingi Dahlan 
HM Nor berdoa. Terlihat mata mantan Wakil Ketua DPRD Kabupaten Bima itu berkaca-kaca. (Lombok Post, 19/2/2016)

Ibu dua anak yang akrab disapa Dae Dinda ini mengatakan, akan Inspeksi mendadak (Sidak) ke setiap SKPD.... Menurutnya, predikat WTP sudah diperoleh sejak kepemimpinan almarhum H Ferry Zulkarnain.... (Lombok Post, 22/2/2016)

Lima tahun kedepan, ibu dua orang anak ini berkomitmen memperbaiki dunia pendidikan di Bima..... Menurutnya, pelaksanaan pilkada yang aman menjadi modal bagi Kabupaten Bima untuk meyakinkan investor datang berinvestasi.... "Kita akan coba cari titik solusinya," kata istri almarhum H Ferry Zulkarnain Sultan Bima ini. (Lombok Post, 24/2/2016)

Pencanangan ini menjadi penanda kita mulai bekerja. Woha ke depan harus menjadi contoh bagi kecamatan lain." terang ibu dua anak ini. (Lombok Post, 12/3/2016)

Indah Damayanti Putri direpresentasikan dalam teks di atas sebagai pemimpin perempuan dalam kapasitasnya sebagai seorang Bupati, namun kapasitas seorang perempuan sebagai pemimpin tersebut tidak dapat terpisah dari labelnya sebagai seorang ibu rumah tangga. Hal ini ditunjukkan dengan kalimat "ibu dua anak ini" yang berulangkali disebutkan dalam pemberitaan di harian Lombok Post.

Beberapa kalimat yang lain menunjukkan adanya subordinasi laki-laki terhadap perempuan. Kalimat dalam teks berita secara tersirat menunjukkan hal tersebut, penegasan bahwa Indah Damayanti Putri adalah istri mantan Bupati Bima menjadi penanda bahwa teks ini mengatakan keberhasilannya terpilih sebagai pemimpin di daerah Bima bukanlah semata-mata karena kemampuan dan kualitasnya, namun dipengaruhi oleh faktor kekuatan penting dari kaum laki-laki. Asumsi ini diperkuat dengan berita yang berjudul “Jangan Lupa Ibu Bupati!” dengan teks berita "Tokoh masyarakat Soromandi HM Natsir Sidik mengatakan, warga mulai mendesaknya untuk menanyakan janji politik bupati dan wakil bupati (wabup) saat 
pilkada lalu. "Saat itu bupati dan wabup berjanji akan meneruskan program almarhum H Ferry Zulkarnain. Yakni pengaspalan jalan di Dusun Mbubu dan pembangunan Masjid,” katanya kemarin. (Lombok Post, 21/4/2016). Pengulangan kalimat "istri mendiang almarhum H Ferry Zulkarnain" dalam teks berita, secara implisit penulis berita telah mengarahkan pembaca bahwa politisi perempuan yang kebetulan saat ini menjadi pemimpin memiliki ikatan dengan figur publik yang sangat dikenal oleh masyarakat, yakni sebagai istri dari mendiang Sultan Bima. Hubungan antara politisi perempuan dengan figur prominence dari keluarga, baik itu mantan suami, mendiang suami, ayah dan lain sebagainya seakan menjadi hal yang penting untuk diketahui pembaca.

Sementara dalam judul berita "Dinda Rayu DPRD, HBY Belum Masuk Pendopo" diikuti dengan teks "Kehadiran kami di dewan ini untuk silaturahmi, sekaligus berdiskusi lepas tentang daerah," terang istri almarhum Sultan Bima H Ferry Zulkarnain ini (Lombok Post, 22/2/2016). Kata "Rayu yang digunakan dalam judul tersebut menunjukkan kata kerja, dalam Kamus Besar Bahasa Indonesia berarti membuat sedih, membuat hati merasa sedih, mengibakan hati (http://kbbi.co.id/arti$\underline{\mathrm{kata} / \mathrm{rayu}}$ ). Penggunaan kata ini secara implisit ingin menunjukkan kepada pembaca bahwa sekalipun ketika seorang perempuan menjadi pemimpin maka sisi-sisi keperempuanan tidak dapat dilepaskan. Sebagaimana anggapan umum di masyarakat bahwa perempuan itu lemah, cengeng, irrasional, manja, dan sebagainya. Anggapan umum yang berkembang dalam masyarakat ini pun coba dihadirkan dalam teks pemberitaan di harian Lombok Post.

Teks berita lainnya juga menonjolkan sisi keperempuanan dari figur Bupati Indah Damayanti Putri, terdapat dalam judul berita "Bupati Cantik Hibahkan Tanah untuk Polda” (Lombok Post, 17/3/2016). Terdapat juga dalam judul berita: "Unpad Kepincut Hadirkan Bupati Cantik” (Lombok Post, 23/3/2016), repetisi kata cantik terdapat dalam judul berita yang berbeda "Ada Kebakaran, Bupati Cantik Tetap Tenang" (Lombok Post, 31/3/2016); "Bupati Cantik Kepincut Karya Siswa SMK" 
(Lombok Post, 3/3/2016). Penulis berita berulang kali menonjolkan pilihan kata "Bupati cantik" untuk menegaskan bahwa figur sang pemimpin adalah perempuan. Sisi feminis seakan-akan menjadi hal penting untuk ditegaskan, tentunya hal ini tidak akan muncul apabila pemimpin daerah tersebut berbeda gender.

Selain kata "cantik", penulis berita juga ingin mengatakan kepada pembaca bahwa fakta terpilihnya Indah Damayanti Putri sebagai pemimpin di Kabupaten Bima merupakan fakta yang unusualness. Misalnya terdapat dalam berita berjudul: "Catat, Ini Janji Bupati Cantik" dengan teks berita "kita sudah koordinasikan dengan pihak provinsi. Melaporkan jembatan yang ambruk tersebut," sebutnya. Bupati perempuan pertama di NTB ini berjanji akan memperjuangkan pembangunan jembatan tersebut. Ia meminta masyarakat Soromandi bersabar. (Lombok Post, 18/3/2016); Judul: "Perempuan Bisa Bangun Daerah" dengan teks berita "Di mata bupati perempuan pertama di Indonesia Timur ini, Kartini merupakan tokoh emansipasi wanita. Sangat penting untuk memperingati Hari Kartini. Sosoknya motivasi bagi perempuan untuk selalu memperjuangkan hak-hak wanita di Indonesia." (Lombok Post, 22/4/2016). Penulis berita menegaskan kembali kepada pembaca bahwa figur pemimpin tersebut merupakan pemimpin perempuan pertama di NTB, bahkan disebutkan dalam skala yang lebih besar yaitu di wilayah Indonesia Timur. Media kembali merepresentasikan bahwa sosok pemimpin perempuan adalah sesuatu yang di luar kebiasaan, sehingga figur sang Bupati menjadi luar biasa.

Hal ini sejalan dengan pernyataan sekretaris redaksi Lombok Post yang disampaikan kepada peneliti dalam wawancara yang dilakukan pada tanggal 2/12/2016 di kantor harian Lombok Post. Terpilihnya Indah Damayanti Putri sebagai kepala daerah perempuan pertama di NTB merupakan fakta yang unik dan menarik. Oleh karenanya harian Lombok Post memberikan porsi pemberitaan yang lebih besar kepada figur pemimpin perempuan ini dibandingkan dengan figur kepala daerah lain di wilayah NTB yang notabene adalah laki-laki. Selain porsi pemberitaan yang lebih besar, kalimat yang menyatakan bahwa Indah Damayanti Putri adalah pemimpin perempuan pertama di NTB secara berulangkali merupakan upaya redaktur untuk 
memberikan penekanan bahwa kejadian atau fakta kepemimpinan perempuan di Kabupaten Bima NTB adalah sebuah hal yang tidak biasa atau unusualness.

Representasi citra perempuan dalam politik yang diwacanakan oleh Lombok Post melalui teks beritanya adalah hasil rutinitas kerja redaksi dalam memproduksi berita. Rutinitas proses produksi berita di harian Lombok Post melibatkan berbagai pihak, mulai dari wartawan sebagai pencari dan penulis berita, editor yang dalam hal ini dipegang oleh redaktur sebagai pihak yang memastikan bahwa berita sudah clear untuk dipublikasi, selanjutnya masuk tahapan editing oleh pihak pimpinan redaksi yang mempunyai kewenangan akhir dalam menentukan apakah berita layak untuk terbit atau tidak. Berbagai peran dalam redaksi tersebut sebagian besar dimainkan oleh laki-laki. Secara umum komposisi redaktur di harian Lombok Post adalah 70\% laki-laki dan $30 \%$ sisanya adalah perempuan. Secara khusus, pihak-pihak yang terlibat dalam proses produksi berita bagian politik adalah laki-laki. Kondisi ini tentunya mempengaruhi cara pandang terhadap citra perempuan dalam politik, yang akhirnya akan mempengaruhi cara mengemas berita tentang kepemimpinan perempuan dalam politik.

\section{Analisis Wacana Pemberitaan Politisi Perempuan Indah Dhamayanti Putri di Surat Kabar Harian Suara NTB}

Sebagaimana teks berita di harian Lombok Post yang secara tersirat merepresentasikan subordinasi laki-laki terhadap perempuan. Harian Suara NTB pun mewacanakan hal serupa dalam teks beritanya, misalnya:

Kini Kabupaten Bima resmi dipimpin Bupati definitif, $\mathrm{Hj}$. Indah Dhamayanti Putri periode 2016-2021. Bahkan istri mendiang almarhum H. Ferry Zulkarnain, ST ini, mencatatkan namanya sebagai Kepala Daerah perempuan pertama di NTB. (Suara NTB, 19/2/2016)

Tidak hanya itu, Pemkab Bima di bawah kepemimpinannya juga bertekad meraih predikat wajar tanpa pengecualian (WTP) dalam hal pengelolaan 
keuangan. "Kita juga akan fokus menata pemerintahan yang baik, sehingga dapat meraih WTP," pungkas istri mendiang almarhum Bupati Bima, H. Ferry Zulkarnain, S.T ini. (Suara NTB, 23/2/2016)

Pengulangan teks berita tentang figur Indah Dhamayanti Putri sebagai istri mantan Bupati Bima sebelumnya menjadi penandan bahwa dominasi laki-laki terhadap perempuan akan selalu melekat dalam berbagai sektor, termasuk dalam politik. Serupa dengan harian Lombok Post, di harian Suara NTB juga di tuliskan dalam beritanya bahwa sang Bupati Bima terpilih adalah Kepala Daerah perempuan pertama di NTB. Hal ini dirasa penting diketahui oleh masyarakat, sebab peristiwa ini adalah sebuah peristiwa yang tidak biasa terjadi.

Jika di harian Lombok Post representasi sisi feminisme ditampilkan dengan menghadirkan kata-kata "cantik", "rayu", "ibu dua anak", maka senada dengan Lombok Post, harian Suara NTB juga merepresentasikan sisi feminisme sang Bupati melalui rangkaian antar kalimat. Berita dengan judul "Bupati Bima Sidak Seluruh Kantor Lingkup Setda" merepresentasikan sisi-sisi feminisme dari kepemimpinan Indah Dhamayanti Putri, berikut teks beritanya:

Ketika memasuki ruang kerja Bagian Keuangan, Bupati secara khusus berpesan agar pegawai menyiapkan pot bunga di dalam ruangan sehingga kelihatan lebih asri dan ruangan tertata rapi..... Disela sidaknya itu, istri mendiang almarhum Bupati Ferry Zulkarnain ini mengingatkan kepada pegawai agar tetap memperhatikan kebersihan ruangan. Sebab kebersihan ruangan penting agar para pegawai merasa nyaman dalam bekerja. "Ruangan yang bersih, masyarkat yang mendapatkan pelayanan juga nyaman dengan situasi di ruang kantor," katanya..... "ASN yang mengabdi di lingkungan pemerintahan, khususnya di Setda merupakan pegawai pilihan. Oleh karen itu disamping kedisiplinan, penampilan dan tata cara berpakaian perlu diperhatikan," terangnya. Di samping itu, ASN perempuan menggunakan kerudung berseragam, minimal di masingmasing bagian. hal tersebut penting dilakukan, karena selain menjadi identitas, keseragamam juga akan terlihat lebih cantik. (Suara NTB, 26/2/2016)

Teks berita tersebut secara detail menggambarkan berbagai hal yang menjadi perhatian Indah Dhamayanti Putri sebagai kepala daerah sekaligus seorang perempuan dalam menjalankan roda pemerintahannya. Berbagai hal tersebut adalah 
kebersihan, penampilan dan tata cara berpakaian, yang dalam anggapan umum masyarakat Indonesia merupakan aktifitas yang melekat pada perempuan.

Berbeda dengan penyajian pemberitaan tentang Indah Damayanti Putri di harian Lombok Post yang cenderung menyajikan berita-berita positif terkait dengan sosok, aktifitasnya dalam pemerintahan, dan kebijakan sang Bupati. Pemberitaan di harian Suara NTB cenderung pemberitaan yang bersifat mengkritisi kinerja sang Bupati dalam menjalankan roda pemerintahan.

Analisis terhadap representasi dalam rangkaian antarkalimat di harian Suara NTB menunjukkan bahwa politisi perempuan dianggap kurang piawai dalam menjalankan roda pemerintahan. Representasi dalam rangkaian antarkalimat berhubungan dengan bagian mana dalam kalimat yang lebih menonjol dibandingkan dengan yang lain. Rangkaian antarkalimat yang merepresentasikan hal tersebut misalnya dalam berita berjudul "Korban Banjir di Bima Keluhkan Lambannya Bantuan" (Suara NTB, 17/3/2016). Secara prinsip berita tersebut telah memenuhi persyaratan, yaitu cover both side, pihak-pihak yang terkait dengan peristiwa tersebut dimasukkan dalam teks berita.

Namun jika mengacu pada format penulisan berita piramida terbalik, maka pernyataan yang diungkapkan oleh Bupati Indah Dhamayanti Putri terkait dengan respon pemerintah terhadap korban banjir dianggap kurang penting. Pasalnya pernyataan dari Bupati Bima tersebut dituliskan pada bagian terakhir dalam teks berita. Sementara pada bagian awal berita didominasi oleh pernyataan dari korban banjir yang belum mendapatkan perhatian dan bantuan dari pemerintah sementara bencana banjir telah berlangsung selama lima hari. Pernyataan korban banjir tersebut diperkuat dengan pernyataan dari legislatif yang juga mengkritisi lambannya kerja eksekutif, dalam hal ini Bupati Indah Dhamayanti Putri. Penulisan berita dengan format piramida terbalik dimulai dengan ringkasan atau klimaks dalam alinea pembukanya, kemudian dikembangkan lebih lanjut dalam alinea-alinea berikutnya 
dengan memberikan rincian cerita secara kronologis atau dalam urutan yang semakin menurun daya tariknya (Kusumaningrat, 2012: 126).

Representasi kinerja pemimpin perempuan yang kurang piawai ini secara implisit juga terbaca dari berita yang berjudul "Bupati Bima Didesak Tempati Kantor Baru" (Suara NTB, 22/3/2016). Berita ini secara dominan menarasikan tentang tuntutan aktivis HMI Komisariat STKIP Taman Siswa terhadap Bupati Bima Indah Dhamayanti Putri agar segera menempati kantor baru untuk kepentingan pelayanan publik, sebagai bukti janji politiknya. Serta menuntut Bupati untuk membangun infrastruktur daerah setempat yang belum memadai, menjalankan roda pemerintahan berdasarkan aturan dan mekanisme yang ada, tidak bekerja sesuai selera ataupun sistem balas dendam. Hanya pada paragraf terakhir dituliskan tentang respon Bupati Bima terkait dengan tuntutan tersebut.

Judul berita "Dua Kali Festival Tambora, Kabupaten Bima Mengekor" juga merepresentasikan ketidakpiawaian seorang Indah Dhamayanti Putri sebagai seorang kepala daerah. Penggunaan kata "mengekor" mengindikasikan bahwa pemerintah hanya bisa menjadi bagian terbelakang dan pengikut dari pemerintah di daerah lain. Hal ini dipertegas dalam teks berita berikut:

.... Sementara Kabupaten Bima hanya bisa berpartisipasi dan mengekor dalam acara yang 2015 lalu terkenal Tambora Menyapa Dunia (TMD) dan 2016 ini menjadi Festival Pesona Tambora (FPT). "Tahun ini kali kedua festival digelar. Kabupaten Bima hanya sebagai partisipan," ucap Bupati Bima, Hj Indah Dhamayanti Putri.... Bupati Bima menjelaskan secara administratif wilayah Tambora sebagian besar masuk dalam pemerintahan Kabupaten Bima. Termasuk kawasan Taman Nasional Tambora yang kini dikelola oleh Badan Konservasi Sumber Daya Alam (BKSDA). (Suara NTB, 14/4/2016)

Bagian awal teks berita menyebutkan pemerintah Bima hanya bisa menjadi partisipan dalam festival Tambora, namun pada teks berikutnya Bupati menjelaskan bahwa secara administratif sebagian besar wilayah Tambora masuk dalam 
pemerintahan Kabupaten Bima. Teks berita ini secara implisit ingin mengatakan kepada pembaca bahwa Indah Dhamayanti Putri sebagai kepala daerah kurang dapat melakukan lobi politik dengan kepala daerah di wilayah sekitarnya yang notabene dikepalai oleh laki-laki. Roda pemerintahan di bawah kepemimpinan seorang perempuan akan berjalan kurang optimal.

Judul berita "Pedagang Pasar Tente Demo Bupati Bima" juga merepresentasikan lemahnya kepemimpinan perempuan. Teks berita yang lebih dominan menarasikan kekecewaan para pedagang akibat ketidakadilan yang ditimbulkan oleh adanya relokasi, dibanding dengan teks berita yang menarasikan kebijakan pemerintah terkait dengan masalah tersebut. Cara penyajian yang demikian tentunya menyudutkan posisi pemerintah dalam konteks ini pemerintah yang dikepalai oleh seorang perempuan. Bahkan dalam teks berita dituliskan "Ironisnya baik di DPRD maupun di Kantor Bupati, aksi para pedagang itu tidak ditanggapi oleh dua lembaga tersebut sehingga sempat diwarnai tangisan histeris”. (Suara NTB, 13/5/2016)

Representasi yang demikian juga terdapat dalam berita dengan judul "DPRD Bima Soroti Kinerja Eksekutif”, dengan teks berita sebagai berikut:

Sejak dilantik menjadi Bupati dan Wakil Bupati Bima, Februari lalu, Pemkab Bima di bawah kendali Hj. Indah Dhamayanti dan Drs. Dahlan M. Noer, dinilai belum efektif dalam menjalankan roda pemerintahan. Sebab aktivitas kegiatan keduanya, kebanyakan di luar daerah, yang juga diikuti oleh SKPD Pemkab setempat.... "Kami menilai, Bupati dan Wakil Bupati ke luar daerah, fungsi pengawasan dan kontrol kepada SKPD tidak ada. Imbasnya pelayanan yang diberikan kepada masyarakat mandek," katanya. Dia menilai lima hari kerja yang diberlakukan oleh Pemkab Bima disarankan ditinjau kembali. Pasalnya selama ini, pelayanan yang diberikan kepada masyarakat kurang efektif dan tidak maksimal. (Suara NTB, 31/5/016).

Teknik penulisan yang sama dengan beberapa berita di atas, bahwa teks berita yang berisi pernyataan dari pihak-pihak yang tidak puas terhadap kinerja Bupati 
Indah Dhamayanti Putri lebih dominan dibandingkan teks berita yang berisi pernyataan dari Bupati tentunya akan merugikan posisi sang Bupati, dalam hal ini terkait dengan reputasinya sebagai seorang kepala daerah.

Terlepas dari apakah berita yang disajikan oleh masing-masing surat kabar tersebut cenderung positif atau cenderung negatif terhadap figur kepemimpinan Indah Dhamayanti Putri sebagai kepala daerah, namun tentunya pengemasan berita yang disesuaikan dengan kepentingan media ini akan memberikan dampak yang cukup signifikan kepada masyarakat terkait dengan persepsi masyarakat terhadap kepemimpinan perempuan di bidang politik.

\section{KESIMPULAN DAN SARAN}

Dari hasil analisis wacana konstruksi media pada politisi perempuan Indah Dhamayanti Putri di media massa, yang dalam hal ini adalah media lokal Lombok Post dan Suara NTB, melalui penelitian ini penulis berharap bisa memberikan gambaran bagaimana media mengilustrasikan stereotype, pencitraan pada figur politisi perempuan yang menjabat sebagai kepala daerah kepada publik.

Keberadaan perempuan dalam dunia politik yang ditampilkan oleh Harian Umum Lombok Post dan Suara NTB melalui sejumlah teks beritanya digambar sebagai sesuatu ketidaklaziman (unusualness) sehingga membutuhkan penekanan berulangkali untuk menegaskan bahwa sang pemimpin kabupaten adalah seorang perempuan.

Stereotip dan subordinasi terhadap perempuan, khususnya di ranah politik masih tetap tampak. Hal ini memang terbentuk karena budaya patriarkhi yang berkembang dalam sistem sosial masyarakat Indonesia. Budaya patriarkhi adalah budaya di mana 
laki-laki memegang kekuasaan atas semua peran penting dalam masyarakat, pemerintah, militer, pendidikan, industri, agama, dan sebagainya. Kehadiran perempuan di ranah politik masih dilihat dari sisi keperempuanannya dan baru terkadang dilihat dari sisi politisinya.

Melalui penelitian ini dapat disimpulkan bahwa kehadiran perempuan di ranah politik masih membutuhkan dukungan untuk meraih kesetaraan yang dicita-citakan terlepas dari label yang menyertainya sebagai perempuan secara fisik, akan tetapi peran dan kemampuannya untuk masuk ke dunia politik dan memegang peran kepemimpinan bisa tumbuh berkembang dengan bebas tanpa perlu dikaitkan kembali adengan perannya di dalam keluarga ataupun label penyerta sebagai pendamping dari seorang figur yang berpengaruh. Dalam hal ini tentunya dibutuhkan media yang mampu merepresentasikan politisi perempuan secara setara dan mengesampingkan label-label yang menegaskan bahwa kehadiran politisi perempuan sebagai sesuatu yang di luar kelaziman. 


\section{DAFTAR PUSTAKA}

Adam, Rainer. 2000. "Media dan Politik," dalam Mirza, Layla S. Politik dan Radio: Buku Pegangan bagi Jurnalis Radio. Friedrich Nauman Stiftung.

Carter, Steiner, 2003, Critical Readings: Media And Gender, McGraw-Hill Education (UK) hal 2 diakses melalui pratinjau https://books.google.co.id/books?id=rWT4AAAAQBAJ\&pg=PT28\&lpg=PT28\&dq= Carter, + Steiner, $+2003: 2 \&$ source $=$ bl\&ots $=$ aU1MEK8IsG\&sig=FFIocLYksBNdsaSIY $\underline{\text { RmiOE5zym0\&hl=en\&sa }=X \& r e d i r \_e s c=y \# v=\text { onepage } \& q=C a r t e r \% 2 C \% 20 \text { Steiner } \%}$ $\underline{2 \mathrm{C} \% 202003 \% 3 \mathrm{~A} 2 \& \mathrm{f}=\text { false }}$

Eriyanto. 2001. Analisis Wacana: Pengantar Analisis Teks Media. Yogyakarta: LKiS.

Handayani, Trisakti, dkk. 2002. Konsep dan Teknik Penelitian Gender. Malang: UMM Press.

Indriyati, dkk. 2005. Masih dalam Posisi Pinggiran: Membaca Tingkat Partisipasi Politik Perempuan di Kota Surakarta. Solo: SPEK-HAM.

Pawito. 2007. Penelitian Komunikasi Kualitatif. Yogyakarta: LKiS.

Saptari, Ratna \& Holzner, Briggite. 1997. Perempuan, Kerja dan Perubahan Sosial. Jakarta: Pustaka Utama Graffiti

Sobur, Alex. 2002. Analisis Teks Media: Suatu Pengantar untuk Analsis Wacana, Analisis Semiotik, dan Analisis Framing. Bandung: Remaja Rosdakarya.

Sugiarti, dkk. 2003. Pembangunan Dalam Perspektif Gender. Malang: UMM Press. 
